\title{
Double Output 2.4 GHz Square Frame Antenna for Doppler Wireless Sensor
}

\author{
Irfan Mujahidin ${ }^{\mathrm{a}, 1,{ }^{*}}$ Rahman Arifuddin ${ }^{\mathrm{b}, 2}$ \\ a,b Department of Telecommunication Labortory, Faculty of Engineering, University of Merdeka Malang, Malang, \\ Indonesia \\ ${ }^{1}$ irfan.mujahidin@unmer.ac.id* ; ${ }^{2}$ rahman.arifuddin@unmer.ac.id
}

\begin{tabular}{|c|c|}
\hline & ABSTRACT \\
\hline $\begin{array}{l}\text { Keywords } \\
\text { Microstrip antenna } \\
\text { Power Devider } \\
\text { Square frame patch }\end{array}$ & $\begin{array}{l}\text { The wireless sensor organizes framework requires cost recurrence, the complex } \\
\text { electromagnetic circuit to form two yield radio wire with the same control flag, and } \\
\text { reasonable fabric, particularly for the electromagnetic component. } 2.4 \mathrm{GHz} \text { square } \\
\text { frame-shaped fixed microstrip Receiving wire with Twofold Yield that has the same } \\
\text { control utilizing control divider for the doppler wireless sensor has been proposed. this } \\
\text { is often the novel formed microstrip Receiving wire with the free recurrence, more } \\
\text { straightforward setup, and low-cost fabric at the } 2.4 \mathrm{GHz} \text { for doppler wireless sensor. } \\
\text { This framework is a critical portion component of the doppler wireless sensor that's } \\
\text { bundle comprises of a } 2.4 \mathrm{GHz} \text { radio wire with the square outline fix and control divider } \\
\text { which is single input with double yield with the same control. The Radio wire has limit } \\
\text { transmission capacity with the recurrence is } 2.38-2.41 \mathrm{GHz} \text { beneath }-15 \mathrm{~dB} \mathrm{~S} \text { parameter } \\
\text { and recurrence reverberation } 2.4 \mathrm{GHz} \text { the radiation design is directional and the pick up } \\
\text { is } 4.52 \mathrm{~dB} \text {, The Control divider has } \mathrm{S} \text { parameter } 3 \text { ports beneath }-20 \mathrm{~dB} \text { at } 2.4 \mathrm{GHz} \text { and } \\
\text { separation over - } 4 \mathrm{~dB} \text { that's } 11 \text { great assention. The circular wonderfulness of the propose } \\
\text { recieving wire framework is } 100 \mathrm{~mm} \text { times } 55.7 \mathrm{~mm} \text { with copper plated fabric too called } \\
\text { FR } 4 \text { with } 4.4 \text { of dielectric steady. }\end{array}$ \\
\hline
\end{tabular}

\section{Introduction}

in the present time, the development of war technology turned to more useful technology for the process of life. as well as wireless sensor system technology which is better utilization of radar systems that were previously specialized in transportation and war. wireless sensor technology requires a practical, compact, inexpensive and efficient antenna[1][2].

Now starting to be developed the radar configuration for wireless sensor technology with suitable specifications for researchers, namely the doppler radar technique. with the reason, A generous deviation dc-coupled radar continuous-wave configuration with an elevated signal to noise ratio on doppler wireless sensor is adequate of accurate liaison unit of human adult subjects. Basically, doppler wireless sensors have two antennas, each antenna as a transmitter and receiver[3][4]. the configuration can be seen in figure 1. Electromagnetic waves before and after the antenna are transmitted must be connected to electronic devices to share the power signal with the same power size.

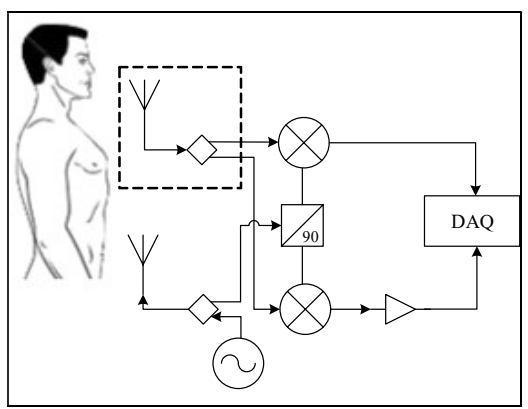

Fig. 1.Doppler Wireless Sensors 
Integrating the antenna with signal splitter has a consequence in a complicated structure electric configuration, sumptuous, and complicated fabrication to get two output from one antenna with the same power[5][6]. In addition, This entails sumptuous material since the advanced-frequency antenna entails the substance with the weakest loss. Furthermore, Free frequency wireless devices that are already widely used are expected to be more usable for wireless sensor dopplers with more noncomplex and low-cost antenna devices[7][8].

In this manuscript, a tight antenna is composed of a $2.4 \mathrm{GHz}$ square frame patch microstrip antenna and two output power dividers with a directional radiation pattern for doppler wireless sensor and communication applications[9]. This procures serve a plain and capable way for sly a square outline with two receiving wire yield without complex setup circuit plan and manufacture prepare besides utilizing low-cost materials at a free recurrence that's $2.4 \mathrm{GHz}[10]$.

\section{The Proposed Resarch Method}

In this investigation, it is committed to the plan and execution of a square outline radio wire that coordinates with the control divider is utilized for doppler wireless sensors. in figure 2 is appeared the geometry of the proposed miniaturized $2.4 \mathrm{GHz}$ square frame patch Antenna[11][12]. In this Figure 2., single transmission lines $\lambda / 4$ connected to square patch and two frames have been constructed using a copper with the thickness $0.035 \mathrm{~mm}$.

Table 1. Dimensions of Antenna

\begin{tabular}{cc}
\hline Variable & $\begin{array}{c}\text { Dimensions } \\
(\mathbf{m m})\end{array}$ \\
\hline $\mathrm{Ws}$ & 55.7 \\
\hline $\mathrm{Ls}$ & 49.2 \\
\hline $\mathrm{Wp}$ & 38.7 \\
\hline $\mathrm{Lp}$ & 29.25 \\
\hline $\mathrm{La}$ & 12 \\
\hline $\mathrm{Lb}$ & 12 \\
\hline $\mathrm{Wb}$ & 2 \\
\hline $\mathrm{Wt}$ & 0.73 \\
\hline $\mathrm{Lt}$ & 5 \\
\hline $\mathrm{Lr}$ & 5 \\
\hline $\mathrm{Wr}$ & 1.5 \\
\hline
\end{tabular}

This radio wire has one fix square molded as emanating component with two outlines within the upper and lower corners in arrange to center the fix emanating towards the front of the receiving wire of the antenna :

$W p=\frac{v_{0}}{2 f_{r}} \sqrt{\frac{2}{\epsilon_{r}+1}}$

$L p=\frac{1}{2 f_{r} \sqrt{\epsilon_{r e f f}} \sqrt{\mu_{0} \epsilon_{0}}}-2 \Delta L$

Where $\mathrm{Wp}$ is the fixed width, Lp is the fixed length, $v 0$ is the light free-space speed, er is the relative permittivity dielectric of the substrate, and fr is the thunderous recurrence.

In Figure 3. the circuit plan of the proposed miniaturized $2.4 \mathrm{GHz}$ control divider. In this Figure 3 ., the single transmission line $\lambda / 4$ have been developed utilizing an FR4 substrate with a thickness of $0.8 \mathrm{~mm}$. 
Table 2. Dimensions of Antenna

\begin{tabular}{cc}
\hline Variable & $\begin{array}{c}\text { Dimensions } \\
(\mathbf{m m})\end{array}$ \\
\hline $\mathrm{Wa}$ & 30 \\
\hline $\mathrm{La}$ & 40 \\
\hline $\mathrm{Lu}$ & 12 \\
\hline $\mathrm{Wt}$ & 1.5 \\
\hline $\mathrm{Ld}$ & 12.52 \\
\hline $\mathrm{Ls} 1$ & 9.79 \\
\hline $\mathrm{Ws} 1$ & 3 \\
\hline $\mathrm{Ls} 2$ & 9.54 \\
\hline $\mathrm{Ws} 2$ & 3.25 \\
\hline Ls3 & 8.89 \\
\hline $\mathrm{Ws} 3$ & 3.6
\end{tabular}

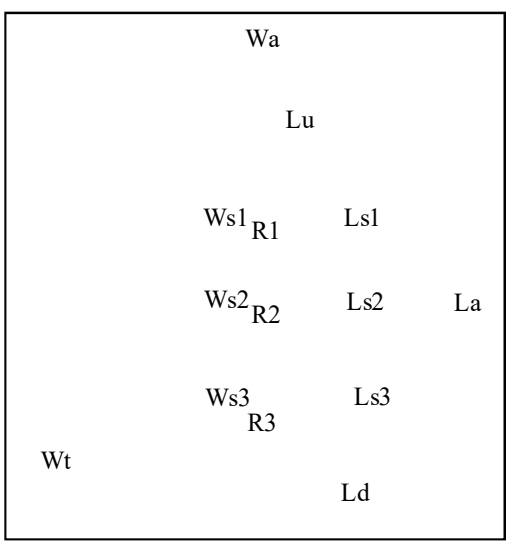

Fig. 3. Effects of selecting different switching under dynamic condition

The operation of the control divider is as takes after: With all ports coordinated, control entering to port 1 is equitably isolated between to ports 2 and 3 as yield, with the same recurrence and same control between these yields at $2.4 \mathrm{GHz}$ recurrence operation. No control is coupled 2 to 1 and 3 to 1 these are disconnected[13][14]. The power divider can follow the Wilkinson Power Divider model, therefore it can be modeled with a stepped multi-section power divider on the following the scheme :

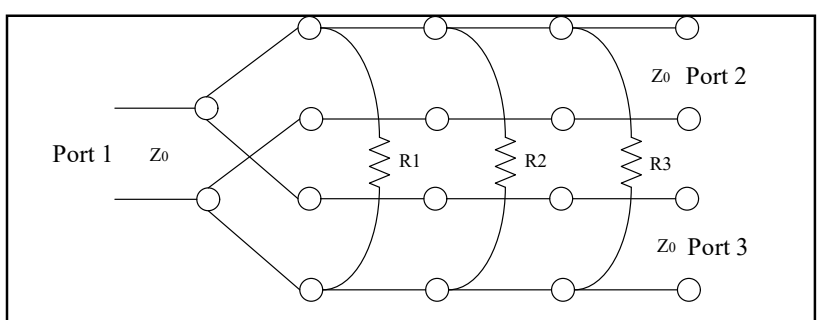

Fig. 4. Scheme of multi-section power divider

The $2.4 \mathrm{GHz}$ antenna specifications as input, the 3 section power devider, the maximum $\mathrm{s}$ parameter $-15 \mathrm{~dB}$, and the equal split $3 \mathrm{~dB}$ then with chebyshev response is obtained impedance matching value $Z 01=91.6 \Omega, Z 02=70.6 \Omega$, and $Z 03=54.5 \Omega$ and with analysis the expected isolation is above $-4 \mathrm{~dB}$, the resistance value can be determain $\mathrm{R} 1=150 \Omega, \mathrm{R} 2=470 \Omega$, and R3 = $820 \Omega$.

\section{Results and Discussion}

Figure 5. appears the model of the square outline microstrip receiving wire for the doppler wireless sensor that has been created. The outline on receiving wire faces is utilized to supply directional radiation to the front[15][16].

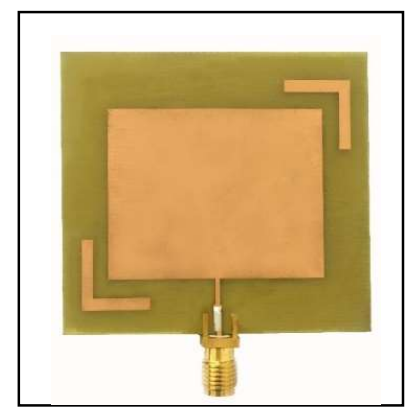

Fig. 5. Physical structure of square frame patch antenna 
To decide the working recurrence of a square outline fix microstrip receiving wire, in Figure 6, it appears the s parameter esteem of the microstrip square outline fix radio wire parameter as a reference.

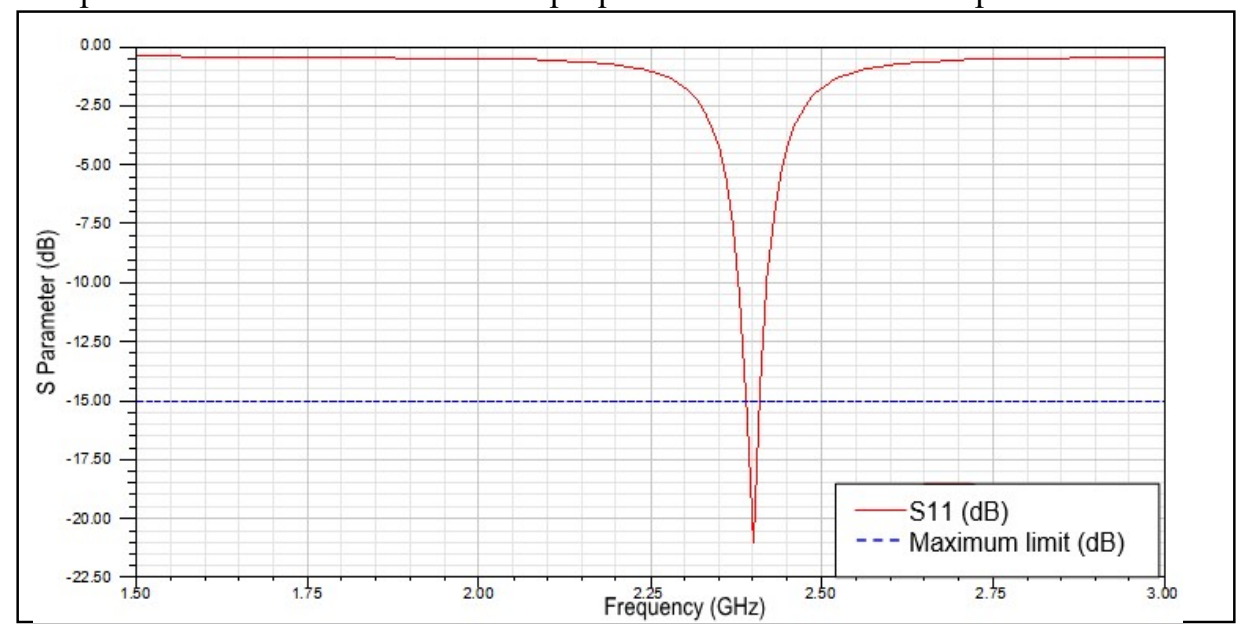

Fig. 6. S parameter of square frame patch microstrip antenna

$\mathrm{S}$ parameter of square frame patch microstrip antenna has good agreement return loss values that are $20.42 \mathrm{~dB}$ on $2.4 \mathrm{GHz}$ and have bandwidth $30 \mathrm{MHz}$ in under $-15 \mathrm{~dB}$. with a narrow bandwidth, it can increase the effectiveness of electromagnetic circuits to not using the bandpass filters[17][18].

To draw the outlines properties of far-field square layout settle microstrip radio wire radiation from as a work of spatial organizes (three estimations)[19][20]. It is essential to know the radiation plan of the receiving wire. The taking after Figure 7. is the square outline fix microstrip receiving wire radiation design:

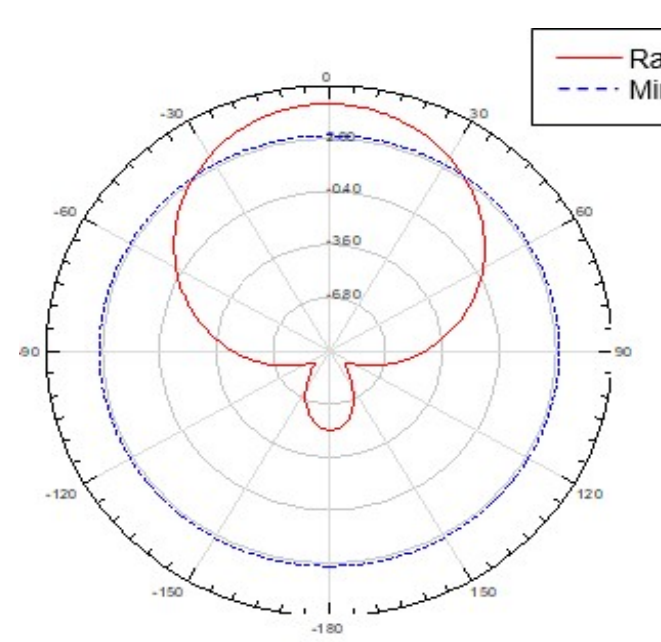

(a)

Fig. 7. (a) Theta angles, and (b) Phi angles of the square frame antenna

The radiation design encompasses a great assertion size of the shape and the value. From the shape of the radiation design contains a primary flap of the biggest and contains an exceptionally little side projection and back flap, it can be concluded that the square outline fix radio wire radiation design could be a directional radiation design[21][22]. To know the reinforcing control in a certain course to the support of the square outline fix antenna reference control thus got to know radio wire pick up esteem[23]. Taking after the pickup esteem : 


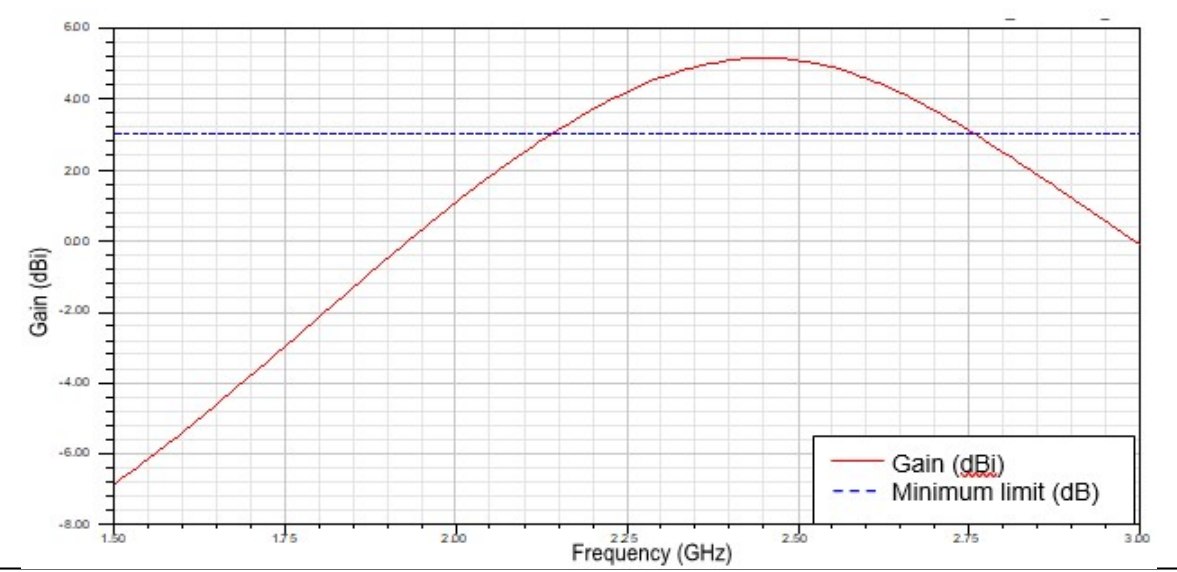

Fig. 8. The gain value square frame patch microstrip antenna

Figure 8. appears that the pick up of the antenna has an esteem of $4.52 \mathrm{dBi}$. this appears that tall radio wire picks up for microstrip receiving wire with the recurrence of $2.4 \mathrm{GHz}$ for a single fix. control divider for square outline fix $2.4 \mathrm{GHz}$ receiving wire is created utilizing the same fabric as the recieving wires FR4 with a moo cost and simple to discover[24][25]. Figure. 10 appears the physical shape of the created control divider for square outline fix $2.4 \mathrm{GHz}$ and Figure. 9 shows up the Sparameter values of each abdicate port[26].

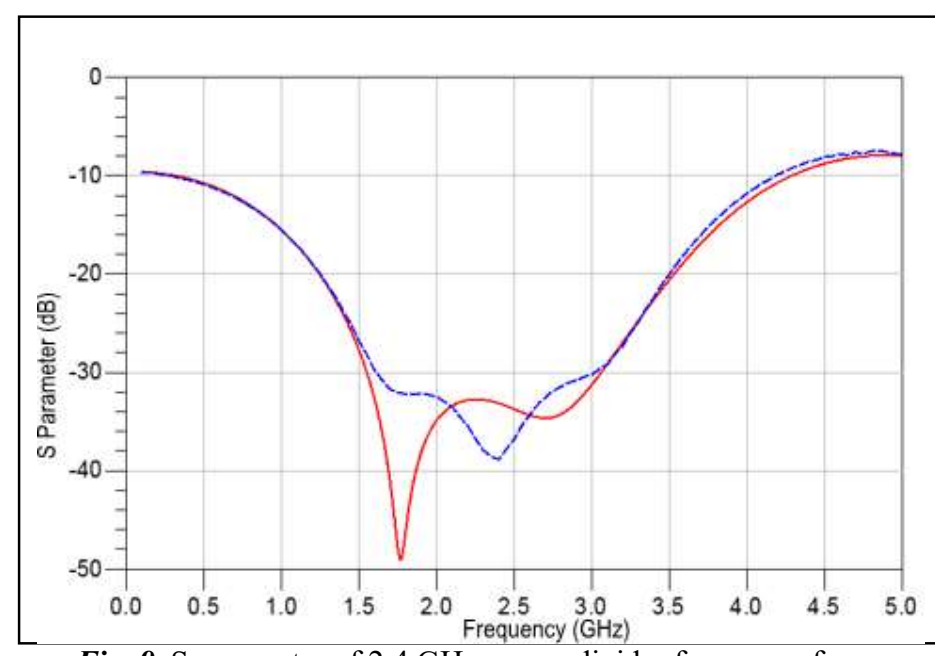

Fig. 9. S parameter of $2.4 \mathrm{GHz}$ power divider for square frame patch antenna

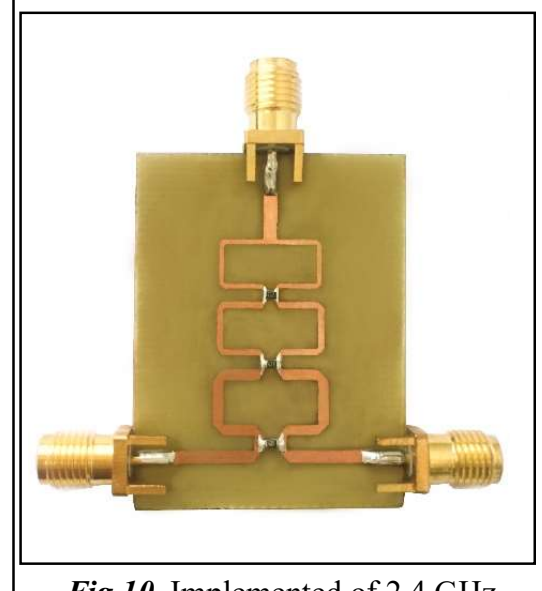

Fig 10. Implemented of $2.4 \mathrm{GHz}$ power divider for the square frame patch antenna

2.4 GHz control divider secure outline fix radio wire employments 3 port SMA male with 50ohm impedance each port[27][28]. $2.4 \mathrm{GHz}$ control divider incorporates a tall degree of symmetry as to isolate the control coupler, as one port can be utilized as the input and two yield port[29][30]. The esteem of S parameter of each port yield at $2.4 \mathrm{GHz}$ recurrence operation can be taken after S12 has esteem -33.15 dB, and S13 has esteem -38.82 dB. 


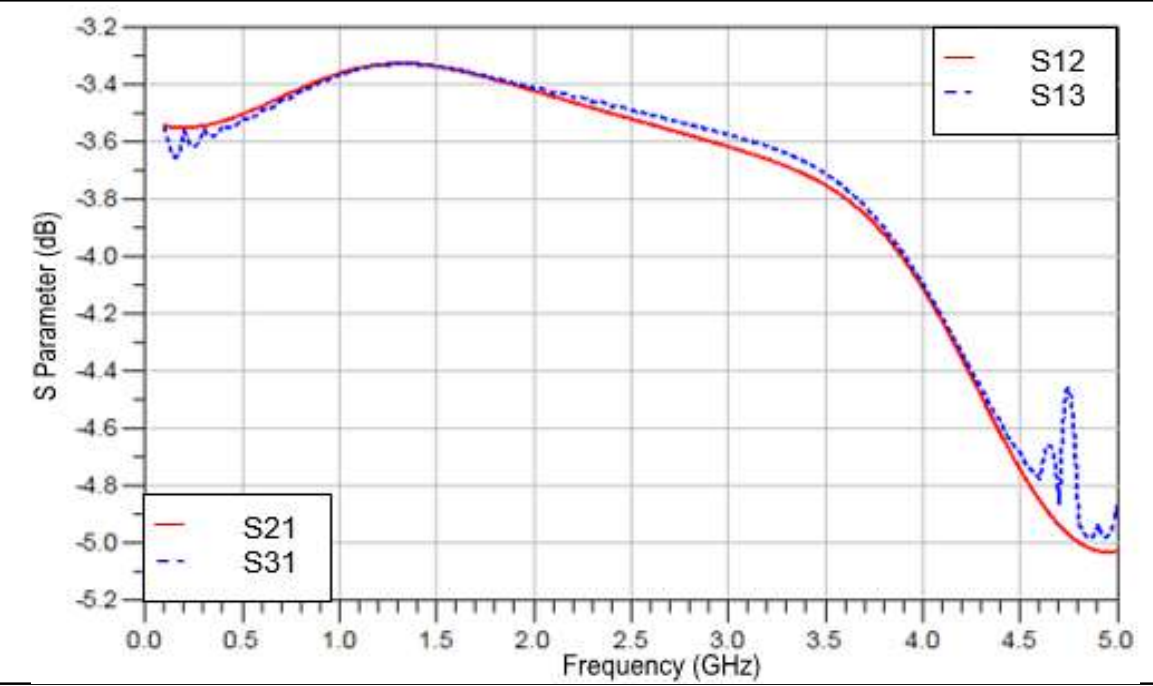

Fig 11. S parameter isolation of the output port

The separation is spoken to in s parameters S21 and S31 with the taking after values S21 have segregation esteem $-3.50 \mathrm{~dB}$ and S31 have separation esteem -3.47 dB. S21 and S31 have s parameter confinement over $-4 \mathrm{~dB}$ for $\mathrm{fr} 4$ with er $=4.4$. Figure 13. appears the physical shape twofold yield 2.4 $\mathrm{GHz}$ square outline fix microstrip Receiving wire associated with female and female connector generally features a length: $100 \mathrm{~mm}$ and width: $55.7 \mathrm{~mm}[31]$.

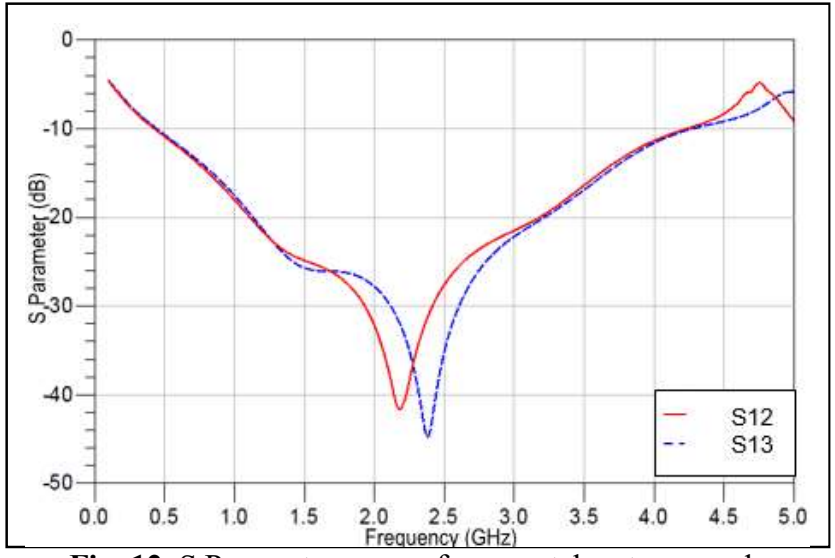

Fig. 12. S Parameter square frame patch antenna and power divider integration

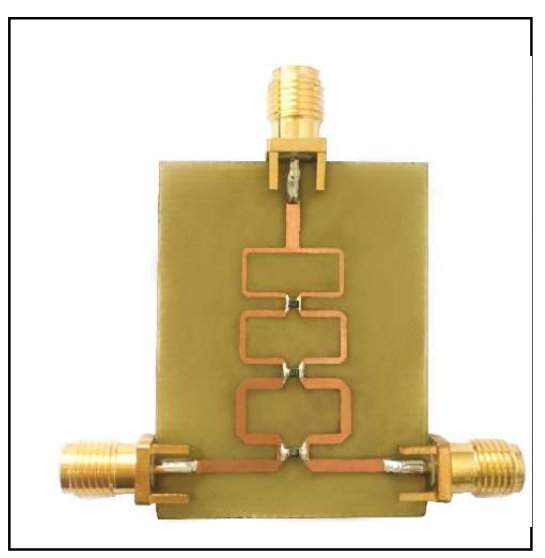

Fig. 13. Implemented square frame patch antenna and power divider integration 
Figure 12. shows up the abdicate $\mathrm{S}$ parameters regard the Radio wire and control divider integration. The S11 and S21 values of the twofold surrender $2.4 \mathrm{GHz}$ square layout settle microstrip Accepting wire, S1 1 highlights regard of $-43.86 \mathrm{~dB}$, and S21 has $-30.45 \mathrm{~dB}$. This shows up that the getting wire execution can work well on that repeat.

\section{Conclusion}

In this letter, a compact demonstrates a twofold surrender radio wire system, not complex to fabricate and low-cost texture that has FR4 texture with $\varepsilon r=4.4$. This radio wire has single resonators or transmission line $\lambda / 4$ with the working recurrence at the resonator that's $2.4 \mathrm{GHz}$. This radio wire may be a directional getting wire with a tall choice up of $4.52 \mathrm{dBi}$ for a single radio wire, a directional radiation plan, and coordinate polarization. The control divider has single inputs from the getting wire and two yields that provide the same control yield and can be confirmed by $\mathrm{S}$ parameters surrender that underneath $20 \mathrm{~dB}$ that's S1 1 consolidates regard of $-20.17 \mathrm{~dB}$ and S21 has $-30.45 \mathrm{~dB}$. so by and expansive the square settle, radio wire arranges by a control divider contains an awesome understanding for the doppler inaccessible sensor.

\section{References}

[1] R. Yuwono, I. Mujahidin, A. Mustofa, and Aisah, "Rectifier using UFO microstrip antenna as electromagnetic energy harvester,” Adv. Sci. Lett., 2015, doi: 10.1166/asl.2015.6574.

[2] I. Mujahidin, "Directional 1900 Mhz Square Patch Ring Slot Microstrip Antenna For Wcdma," JEEMECS (Journal Electr. Eng. Mechatron. Comput. Sci., 2019, doi: 10.26905/jeemecs.v1i2.2626.

[3] I. Mujahidin, R. Yuwono, and A. Mustofa, "Rancang Bangun Rectifier Antenna Mikrostrip Ufo Pada Frekuensi Ultra Wideband (Uwb) Sebagai Pemanen Energi Elektromagnetik," $J$. Mhs. TEUB, vol. 3, no. 2, 2015.

[4] I. Mujahidin, S. H. Pramono, and A. Muslim, "5.5 Ghz Directional Antenna with 90 Degree Phase Difference Output,” 2018, doi: 10.1109/eeccis.2018.8692872.

[5] M. T. Prakarsa, D. Wahyuni, N. Rachman, and I. Mujahidin, "Optimasi Sistem Komunikasi Dari Ht Dengan Hp Dalam Pelaksanaan Tugas Operasi Tni Ad Menggunakan Metode Dtmf," JASIEK (Jurnal Apl. Sains, Informasi, Elektron. dan Komputer), 2019, doi: 10.26905/jasiek.v1i1.3150.

[6] J. Lasmono, A. P. Sari, E. Kuncoro, and I. Mujahidin, "Optimasi Kerja Peluncur Roket Pada Robot Roda Rantai Untuk Menentukan Ketepatan Sudut Tembak," JASIEK (Jurnal Apl. Sains, Informasi, Elektron. dan Komputer), 2019, doi: 10.26905/jasiek.v1i1.3149.

[7] I. Mujahidin and B. F. Hidayatulail, "2.4 Ghz SQUARE RING PATCH WITH RING SLOT ANTENNA FOR SELF INJECTION LOCKED RADAR,” JEEMECS (Journal Electr. Eng. Mechatron. Comput. Sci., vol. 2, no. 2, 2019.

[8] B. F. Hidayatulail and I. Mujahidin, "Potential Of 77, $78 \mathrm{Mw}$ Red Diode Laser For Photodynamic," JEEMECS (Journal Electr. Eng. Mechatron. Comput. Sci., vol. 2, no. 2, 2019.

[9] I. Mujahidin and P. S. Arinda, "Antena Compact Double Square Marge 2, 6GHz Dengan Output Perbedaan Fase 90 Derajat Untuk Aplikasi LTE," JEECAE (Journal Electr. Electron. Control. Automot. Eng., vol. 4, no. 2, pp. 273-278, 2019.

[10] S. K. Sugiarto, I. Mujahidin, and A. B. Setiawan, "2, 5 GHz Antena Mikrostrip Polarisasi Circular Model Patch Yin Yang untuk Wireless Sensor," JEECAE (Journal Electr. Electron. Control. Automot. Eng., vol. 4, no. 2, pp. 297-300, 2019.

[11] D. A. Prasetya, A. Sanusi, G. Chandrarin, E. Roikhah, I. Mujahidin, and R. Arifuddin, "Small and Medium Enterprises Problem and Potential Solutions for Waste Management," J. Southwest Jiaotong Univ., vol. 54, no. 6, 2019.

[12] I. Mujahidin, "Langkah Desain Antena," http://antenapropagasi.blogspot.com/2016/02/langkah-desain-antena.html. 2018. 
[13] I. Mujahidin, "VSWR (Voltage Standing Wave Ratio) dan Return loss," http://antenapropagasi.blogspot.com/2016/02/vswr-voltage-standing-wave-ratio-dan.html. 2018.

[14] D. M. Pozar, Microwave Engineering 4th Ed. 2014.

[15] R. Yuwono and I. Mujahidin, "Rectifier using UWB microstrip antenna as electromagnetic energy harvester for GSM, CCTV and Wi-Fi transmitter," J. Commun., 2019, doi: 10.12720/jcm.14.11.1098-1103.

[16] T. A. S, A. Rabi', D. Minggu, and I. Mujahidin, "Frequency Hopping Video Real Time Untuk Pengamanan Data Pengintaian Operasi Inteligence Tni," JASIEK (Jurnal Apl. Sains, Informasi, Elektron. dan Komputer), 2019, doi: 10.26905/jasiek.v1i1.3146.

[17] C. E. Balanis, "Antenna Theory: Analysis and Design, 3rd Edition - Constantine A. Balanis," Book. 2005, doi: 10.1049/ep.1982.0113.

[18] D. A. Prasetya, A. Sanusi, G. Chandrarin, E. Roikhah, I. Mujahidin, and R. Arifuddin, "Community Culture Improvisation Regarding Waste Management Systems and Per Capita Income Increase," J. Southwest Jiaotong Univ., vol. 54, no. 6, 2019.

[19] D. A. Ayubi, D. A. Prasetya, and I. Mujahidin, "Pendeteksi Wajah Secara Real Time pada 2 Degree of Freedom (DOF) Kepala Robot Menggunakan Deep Integral Image Cascade," Cyclotr. J. Tek. ELEKTRO, vol. 3, no. 1, 2020.

[20] E. Endrayana, D. H. S. Wahyuni, N. Nachrowie, and I. Mujahidin, "Variasi Ground Plane Antena Collinear Pada Pemancar Telivisi Analog Dengan Frekuensi UHF 442 MHz," JASIEK (Jurnal Apl. Sains, Informasi, Elektron. dan Komputer), vol. 1, no. 2, pp. 149-156, 2019.

[21] A. E. Pambudi, L. Maajid, J. Rohman, and I. Mujahidin, "Aplikasi Penggunaan Joystick Sebagai Pengendalian Remote Control Weapon Station (RCWS) Senjata Mesin Ringan (SMR)," JASIEK (Jurnal Apl. Sains, Informasi, Elektron. dan Komputer), vol. 1, no. 2, pp. 98-105, 2019.

[22] M. Wibowo, S. Suprayogi, and I. Mujahidin, "Rancang Bangun Sistem Pengamanan Rak Senjata M16 Menggunakan Rfid Dan Fingerprint," JASIEK (Jurnal Apl. Sains, Informasi, Elektron. dan Komputer), vol. 1, no. 2, pp. 134-142, 2019.

[23] I. Mujahidin, D. A. Prasetya, A. B. Setywan, and P. S. Arinda, "Circular Polarization 5.5 $\mathrm{GHz}$ Double Square Margin Antenna in the Metal Framed Smartphone for SIL Wireless Sensor," in 2019 International Seminar on Intelligent Technology and Its Applications (ISITIA), 2019, pp. 1-6.

[24] I. Mujahidin, "PLL (Phase Locked Loop), http://antenapropagasi.blogspot.com/2018/11/pll-phase-locked-loop.html. 2018.

[25] I. Mujahidin, "Smart Transducers," http://antenapropagasi.blogspot.com/2018/11/smarttransducers.html. 2018.

[26] I. Mujahidin, D. A. Prasetya, Nachrowie, S. A. Sena, and P. S. Arinda, "Performance tuning of spade card antenna using mean average loss of backpropagation neural network," Int. J. Adv. Comput. Sci. Appl., 2020.

[27] I. Mujahidin, "Directional Couplers," http://antenapropagasi.blogspot.com/2018/11/directional-couplers.html, no. 1. 2018.

[28] I. Mujahidin, "Desain Matematis Antena Mikrostrip," http://antenapropagasi.blogspot.com/2016/02/desain-matematis-antenamikrostrip_17.html. 2018.

[29] I. Mujahidin, "Parameter Antena," http://antenapropagasi.blogspot.com/2016/02/parameter-antena.html. 2018.

[30] I. Mujahidin, "Elemen Antena," http://antenapropagasi.blogspot.com/2016/02/elemenentena.html. 2018.

[31] N. R. Tanguy, B. Wiltshire, M. Arjmand, M. H. Zarifi, and N. Yan, "Highly Sensitive and Contactless Ammonia Detection Based on Nanocomposites of Phosphate-Functionalized Reduced Graphene Oxide/Polyaniline Immobilized on Microstrip Resonators," ACS Appl. Mater. Interfaces, 2020, doi: 10.1021/acsami.9b21063. 